\title{
THE EFFECT OF SNAKE AND LADDER GAME ON STUDENT LEARNING OUTCOMES IN STUDYING OF ISLAMIC HISTORY "FATHU MECCA" AT THE ELEMENTARY SCHOOL MUHAMMADIYAH, NORTH SUMATERA, INDONESIA
}

\author{
Rora Rizky Wandini' ${ }^{1}$, Emeliya Sukma Dara Damanik ${ }^{2}$, \\ Sholihatul Hamidah Daulay ${ }^{3}$, Wahyu Iskandar ${ }^{4}$ \\ Universitas Islam Negeri Sumatra Utara, Indonesia ${ }^{1,2,3,4}$ \\ E-mail: rorarizkiwandini@uinsu.ac.id ${ }^{1}$,emeliya@uinsu.ac.id ${ }^{2}$, \\ sholihatulhamidah@uinsu.ac.id ${ }^{3}$, wiskandar921@ gmail.com ${ }^{4}$
}

DOI: 10.14421/al-bidayah.v13i1.637

\begin{abstract}
This study examines the effect of the snake and ladder game on Islamic history Fathu Mecca learning outcomes based on observations at the SD (Elementary School) Muhammadiyah in Indonesia. Students have been shown to acquire standard competency through the study of Islamic history. This course is very important to build a strong Muslim identity, especially in Islamic School Muhammadiyah. Meanwhile, the snake and ladder game has been used by several educators in the teaching and learning process. This game positively influences students' learning outcomes. Therefore, the authors developed and integrated Islamic history into the snake and ladder game board. This research was a quantitative study conducted on 60 fifthgrade students divided into experiment and control classes. Furthermore, the data were collected using observation, interview, and t-test hypotheses. The results showed that the snake and ladder game positively affects students' learning outcomes in studying Islamic history. Based on the result, this game provides opportunities for students to explore, identify, practice, and understand concepts. The teachers are expected to encourage students to develop skills for discovering knowledge through an inspiring and fun learning atmosphere.
\end{abstract}

Keywords: elementary school; Islamic culture history; learning outcome; snake and ladder game

\section{INTRODUCTION}

Learning is defined as acquiring information and knowledge from past experiences in the social community and the surrounding environment. Meanwhile, learning in school is an interaction between teacher and student ${ }^{1}$. Teachers are demanded to use learning media based on student's needs and educational growth. Furthermore, media is very important in teaching because it increases motivation ${ }^{2}$ and behavior

${ }^{1}$ Rusman, Model-Model Pembelajaran Mengembangkan Profesionalisme Guru (Jakarta: Rajawali Press, 2012).

${ }^{2}$ Meng-Ning Tsai et al., "A Brainstorming Flipped Classroom Approach for Improving Students' Learning Performance, Motivation, Teacher-Student Interaction and Creativity in a Civics Education Class," Thinking Skills and Creativity 38 (December 1, 2020): 100747, https://doi.org/10.1016/j.tsc.2020.100747. 
management ${ }^{3}$ and helps students attain a higher level of thought and real-life application. In addition, it attracts interest in learning. ${ }^{4}$ The use of media also engages students during the teaching-learning process, aids student's retention of knowledge, and illustrates the relevance concept. ${ }^{5}$

In an interview and observation with Elementary School students in North Sumatra, Indonesia, the authors found that several students have difficulties memorizing the history of Islamic Culture. Meanwhile, this course is very important to the students of Islamic School. The mastering of Islamic history is a major requirement of the school to help teenagers build strong identities and character. In addition, it also provides awareness about Islamic history over time and enables the student to realize self-potential, as well as love, spirit, and pride ${ }^{6}$. The study of Islamic history also avoids loss of identity and encourages teenagers to have life goals. Therefore, teenagers are expected to master Islamic history for a strong identity. ${ }^{7}$

Previous studies reported that students usually experience boredom while studying Islamic history due to the teaching method. This finding is in line with another study that stated that uncomfortable situations stimulate boredom. ${ }^{8}$ Meanwhile, this condition affects learning outcomes, prevents students from getting high scores, and cannot memorize all Islamic history Fathu Mecca.

The teaching method used at Islamic school Muhammadiyah Medan, Indonesia, does not fulfill the basic goal of learning. The students need tools to assist learning, such

${ }^{3}$ A. Delamarre et al., "The Interactive Virtual Training for Teachers (IVT-T) to Practice Classroom Behavior Management," International Journal of Human-Computer Studies 152 (August 1, 2021): 102646, https://doi.org/10.1016/j.ijhcs.2021.102646.

${ }^{4}$ Eva Lindasari, Khairil Ansari, and Marice Marice, "Interactive Multimedia Development in Learning of Film Review Text for 8th Grade Students in Senior High School (SMP) 1 Tanjungmorawa," Budapest International Research and Critics in Linguistics and Education (BirLE) Journal 2, no. 4 (November 5, 2019): 355-62, https://doi.org/10.33258/birle.v2i4.522.

5 G. Dirk Mateer, "Using Media to Enhance Teaching and Learning," Using Media to Enhance Teaching and Learning, 2020, https://serc.carleton.edu/sp/library/media/index.html.

${ }^{6}$ Izziah Suryani Mat Resad @ Arshad, Ermy Azziaty Rozali, and Azmul Fahimi Kamaruzzaman, "The Importance of Learning Islamic History and Civilization of Malaysia in the Building of Human Capital and Identity of the Muslim Society in Malaysia," Procedia - Social and Behavioral Sciences, Universiti Kebangsaan Malaysia Teaching and Learning Congress 2011, Volume I, December $17-20$ 2011, Pulau Pinang MALAYSIA, $59 \quad$ (October $17, \quad 2012$ ): 550-57, https://doi.org/10.1016/j.sbspro.2012.09.313.

${ }^{7}$ Farid Panjwani, "The 'Islamic' in Islamic Education: Assessing the Discourse," Current Issues in Comparative Education 7, no. 1 (December 15, 2004): 19-29, https://eric.ed.gov/?id=EJ853846.

${ }^{8}$ Ni'matul Fauziah, "Faktor Penyebab Kejenuhan Belajar Sejarah Kebudayaan Islam (SKI) Pada Siswa Kelas XI Jurusan Keagamaan Di MAN Tempel Sleman” (Skripsi, Yogyakarta, UIN Sunan Kalijaga Yogyakarta, 2013), https://doi.org/10/preview.jpg. 
as the use of media in the classroom. Therefore, this study aims to develop a game to solve student's problem of learning Islamic History Fathu Mecca. A game is defined as an activity that has defined rules ${ }^{9}$. It is applicable to complement the traditional method to support, enhance, and increase student's learning experience ${ }^{10}$. One alternative media applicable for learning Islamic History Fathu Mecca is the snake and ladder game. This media was selected because it is simple and is one of the traditional games for kids. The snake and ladder game is often played among elementary school students and is widely known in several countries. ${ }^{11}$ All children or students find it easy to play the game as a note and read the instructions listed on the board. A minimum of two persons plays it; each player has a pawn and gets the chance to shake the dice with numbers from 1 to 6 . The game board is presented in a "box drawing" form, with each box containing a number, stair, and snake. After shaking the dice, the player runs the pawn based on the total number obtained, and when the players meet the stair, it indicates permission to the run up to the next number. Meanwhile, the player is expected to go down when the dice meets the snake. Therefore, the snake and ladder game is presented as a medium to solve student problems in learning Islamic history Fathu mecca.

Several studies have been conducted on snake and ladder games as a media for education, and this game is categorized as an edutainment approach ${ }^{12}$. It provides a fun and positively influences student's learning outcomes. A previous study showed that the snake and ladder game is useful to capture student's interest and improve learning outcomes. In addition, this media was an effective learning medium. Teacher and student can help each other through the application of this game ${ }^{13}$. Another study found that the snake and ladder game effectively increase student engagement, participation, and

\footnotetext{
${ }^{9}$ Inovimbanashe Zirawaga, Victor Samuel., Olusanya, Adeleye Idowu \& Maduku, "Gaming in Education: Using Games as a Support Tool to Teach History," Journal of Education and Practice 8, no. 15 (2017): 55-64, https://files.eric.ed.gov/fulltext/EJ1143830.pdf.

${ }^{10}$ Carlo Perrotta et al., Game-Based Learning: Latest Evidence and Future Directions (NFER Research Programme: Innovation in Education) (Slough, Berkshire: National Foundation fro Educational Research, 2013), https://www.nfer.ac.uk/nfer/publications/GAME01/GAME01.pdf.

11 Andrew Topsfield, "The Indian Game of Snakes and Ladders," Artibus Asiae 46, no. 3 (1985): 203-26, https://doi.org/10.2307/3250203 https://www.jstor.org/stable/3250203.

${ }^{12}$ R. Mahmud Hairul Aysa Abdul Halim Shitiq, "Using an Edutainment Approach of a Snake and Ladder Game for Teaching Jawi Script," in International Conference on Education and Management Technology (Malaysia, 2010), https://doi.org/DOI:10.1109/ICEMT.2010.5657667.

${ }^{13}$ Epi Nuryanti, "Development Of Snake And Ladder Game As A Learning Media In Special Journal Material To Improve Student Motivation Of Class X Accounting SMK Muhammadiyah 1 Tempel Academic Year 2016/2017”' (Skripsi, Fakultas Ekonomi UNY, 2017), http://eprints.uny.ac.id/52263/.
} 
intelligence during learning ${ }^{14}$. The use of ladder games has proven to be effective in teaching vocabulary and writing.

Furthermore, students easily memorize words with the assistance of the snake and ladder game ${ }^{15}$. This game also explores student's minds to develop writing skills. ${ }^{16}$ The snake and ladder game promotes moral education among students. ${ }^{17}$ Furthermore, due to dynamic societal changes, the educational community has lost interest in virtues and morals. However, the snake and ladder game offers good fun and practical ways of stimulating reward or punishment for students' good or wrong deeds ${ }^{18}$. This game has also been proven to assist students in overcoming cognitive learning difficulties. ${ }^{19}$ Recently, a study assessed snake and ladder game effectiveness on the knowledge of Malnutrition among students in the Selected School of Navi Mumbai. This study showed that the snake and ladder game effectively in cognitive and children's social skill development. In addition, the acceptance of win or loss in the game also bond the close relationship between friends and the entire family ${ }^{20}$.

Therefore, this study examines the effect of the snake and ladder game on student learning outcomes in mastering Islamic history Fathu Mecca. It also aims to integrate this game into the Fathu Mecca course. This study hypothesized that the snake and ladder game is applicable for religious lessons and teachings and cultural values. This study is

${ }^{14} \mathrm{Km}$ Cahya Swastrini, S. Pd Putu Aditya Antara, and S. Psi Luh Ayu Tirtayani, "Penerapan Bermain Ular Tangga Untuk Meningkatkan Kemampuan Kerjasama Kelompok B1 Di TK Widya Sesana Sangsit," Jurnal Pendidikan Anak Usia Dini Undiksha 4, no. 2 (July 22, 2016), https://doi.org/10.23887/paud.v4i2.7764.

15 Meipina, "The Application of Snakes and Ladders Game in Teaching Vocabulary," International Conference on Education and Language (ICEL) 2, no. 0 (May 22, 2014), http://artikel.ubl.ac.id/index.php/icel/article/view/311.

${ }^{16}$ Heni Aprina, “The Influence Of Using Snake And Ladder Game Toward Students' Writing Ability In Recount Text At The First Semester Of The Tenth Grade Of SMAN 1 Ngambur Pesisir Barat In 2017/2018 Academic Year" (Undergraduate, UIN Raden Intan Lampung, 2018), http://repository.radenintan.ac.id/2988/.

${ }^{17}$ E. O. Ibam, T. A. Adekunle, and O. C. Agbonifo, “A Moral Education Learning System Based on the Snakes and Ladders Game," EAI Endorsed Transactions on E-Learning 5, no. 17 (October 3, 2018), https://doi.org/10.4108/eai.25-9-2018.155641.

${ }^{18}$ Mariyln Watson, Developmental Discipline and Moral Education (New York: Routledge, 2008).

${ }^{19}$ Suppiah Nachiappan et al., "Snake and Ladder Games in Cognition Development on Students with Learning Difficulties," Review of Arts and Humanities 3, no. 2 (June 2014): 217-29, http://rahnet.com/journals/rah/Vol_3_No_2_June_2014/15.pdf.

${ }^{20}$ Pratibha Jadhav, "A Study to Assess the Effectiveness of Snake and Ladder Game on Knowledge of Malnutrition among Schoolers in Selected School of Navi Mumbai," Int J Nurs Med Invest 5, no. 1 (2020): 6-10, https://doi.org/10.31690/ijnmi/57. 
expected to enhance student learning outcomes and contribute to knowledge on learning media $^{21}$.

\section{RESEARCH METHODS}

This research is a quasi-experimental study that examines the effect of snake and ladder game on students' learning outcomes in mastering Islamic history Fathu Mecca ${ }^{22}$. A total of 60 students were recruited from two classes as the study sample using random cluster sampling. The samples were then divided into two classes, namely experiment and control. This research includes students from class VA (30) and V B (30). The data were obtained primarily from students' learning outcomes using several tools, including observations, interviews, and t-test hypotheses. Observations were conducted to evaluate the process and record it systematically. ${ }^{23}$ Meanwhile, interviews were used to confirm the collected data and determine whether the tested hypotheses are rejected or accepted. Furthermore, data were analyzed using the Normality and homogeneity test to form Pearson product-moment, coefficient, and T-test.

\section{RESULT AND DISCUSSION}

\section{Pre-test}

The pre-test was conducted before the treatment to observe the students' ability to master Islamic history. The results are presented in the following table.

Table 1

Pre-test

\begin{tabular}{ccc}
\hline Statistic Data & Experiment & Control \\
\hline Lowest & 47,6 & 35,2 \\
\hline Highest & 72,8 & 66,5 \\
\hline Average & 60,2 & 50,85 \\
\hline
\end{tabular}

${ }^{21}$ Doug Bierend, "The Timelessness of Snakes and Ladders," reform, 2015, https://medium.com/reform/the-timelessness-of-snakes-and-ladders-4ae7d205a4e7.

22 Sugiyono, Metode Penelitian Pendidikan: Pendekatan Kuantitatif, Kualitatif Dan R\&D (Bandung: Alfabeta, 2016).

${ }^{23}$ Suharsimi, Dasar Dasar Evaluasi Pendidikan (Jakarta: Bumi Aksara, 2016). 
Table 1 shows that there were differences between the experiment and control class. In the pre-test, the experiment and control class had 60.2 and 50.85, respectively. Meanwhile, this result is in the low category

\section{Post-test}

After the treatment, there was a difference between the experimental and control class as demonstrated in table 2 as follows.

Table 2

Post-test

\begin{tabular}{ccc}
\hline Statistic Data & Experiment & Control \\
\hline Lowest & 49,2 & 55,3 \\
\hline Highest & 64,7 & 82,6 \\
\hline Average & 59,95 & 68,95 \\
\hline
\end{tabular}

Table 2 shows that the experiment and control classes had 68.95 and 59.95, respectively.

\section{Normality in Pre-test}

Table 3

Normality in Pre-test

\begin{tabular}{ccccccc}
\hline \multirow{7}{*}{ Class } & Statistic & df & Sig. & Statistic. & Df \\
\cline { 2 - 7 } & Experiment &, 144 & 28 &, $014^{*}$ &, 898 & 8 \\
\cline { 2 - 7 } & Control &, 136 & 27 &, $180^{*}$ &, 927 & 27 \\
\hline
\end{tabular}

Table 3, based on the normality test, shows a Sig value of 0.14 and 0.180 for experiment and control classes, respectively. Therefore, the data were categorized as normal because the values were greater than 0.05 


\section{Post-Test}

Table 4

Normality in Post-test

\begin{tabular}{clcccccc}
\hline \multirow{7}{*}{ Class } & Statistic & df & Sig. & Statistic. & Df \\
\cline { 2 - 7 } Score & Experiment &, 102 & 28 &, $200^{*}$ &, 962 & 28 \\
\cline { 2 - 7 } & Control &, 100 & 26 &, $200^{*}$ &, 958 & 26 \\
\hline
\end{tabular}

Table 4 shows normal sig values of 0.20 and 0.20 for the experiment and control class, respectively. Therefore, the data were categorized as normal because the values were greater than 0.05 .

Homogeneity Test

Table 5

Homogeneity in Post-test

\begin{tabular}{cccc}
\hline \multicolumn{5}{c}{ Score } \\
\hline Levene Statistic & df1 & df2 & Sig. \\
\hline 9,296 & 1 & 5,86 &, 005 \\
\hline
\end{tabular}

Based on table 5, the data were categorized as homogeny via the homogeneity test with sig value of 0.05 and $F$ score of 5.86 and 5.39.

\section{Hypothesis Test}

This research used the hypothesis test between the experiment and control class to increase students' learning outcomes of mastering Islamic history. The result is shown in table 6:

Table 6

Paired t-test for control class

\begin{tabular}{lccc}
\multicolumn{1}{c}{ Variable } & t-hitung & Sig & Level of Sig. \\
\hline $\begin{array}{l}\text { Pre-test \& Post-tes } \\
\text { N-30 }\end{array}$ & $-12,001$ & 0,000 & 0,05 \\
\hline
\end{tabular}


Table 6 shows a significance of 0.000 , which is lower than 0.05 . Therefore, Ho was not accepted. Furthermore, there were significant differences between pre and posttreatment. The result showed that T negative was -12.001 , which indicates that students' average was low before treatment. Therefore, it was concluded that the treatment had a significant effect on student learning outcomes.

Table 7

Paired t-test for experiment class

\begin{tabular}{lccc}
\hline \multicolumn{1}{c}{ Variable } & t-count & Sig & Level of Sig. \\
\hline $\begin{array}{l}\text { Pre-test \& Post-tes } \\
\text { N-30 }\end{array}$ & $-16,801$ & 0,000 & 0,05 \\
\hline
\end{tabular}

Based on the Paired Sample t-test table, the significance level of 0.000 was less than 0.05 ; hence, Ho was rejected. Therefore, it was concluded that there was a significant difference between the average score of learning outcomes before and after treatment.

The hypotheses concluded that the snake and ladder game significantly affect student's learning outcomes in mastering Islamic History Fathu Mecca. This result confirms the effectiveness of the game in the teaching and learning process. A previous study stated that the snake and ladder game increase and help students in the mastering of English language ${ }^{24}$, and computer networking. The hypotheses showed that the classroom application of this game significantly affected learning outcomes ${ }^{25}$. Another study found that the snake and ladder game improves science cognition. ${ }^{26}$ This game has also been used in learning mathematical subjects ${ }^{27}$ and integrated into the mastering of Asmaul Husna ${ }^{28}$. Therefore, it was recommended that the snake and ladder game be utilized and implemented to enhance students' learning outcomes and increase

${ }^{24}$ Zikriyati Zikriyati and An Fauzia Rozani Syafei, "Teaching Vocabulary to Young Learners through Snake and Ladder Game," Journal of English Language Teaching 7, no. 1 (March 2, 2018): 20815, https://doi.org/10.24036/jelt.v7i1.8480.

${ }^{25}$ Syaad Patmanthara et al., "The Use of Ladder Snake Games to Improve Learning Outcomes in Computer Networking," International Journal of Emerging Technologies in Learning (IJET) 14, no. 21 (November 18, 2019): 243-49, https://www.learntechlib.org/p/217211/.

${ }^{26}$ Mohammad Latiful Amin, Sri Sulistyorini, and Sugianto Sugianto, "The Increase of Students Science Cognitive Using Snake Ladder Media," Journal of Primary Education 8, no. 4 (February 4, 2019): 68-74, https://journal.unnes.ac.id/sju/index.php/jpe/article/view/28754.

${ }^{27}$ Farha and Fauzi L Vitoria, R Ariska, "Teaching Mathematics Using Snakes and Ladders Game to Help Students Understand Angle Measurement," Journal of Physics: Conference Series, 2020, https://doi.org/0.1088/1742-6596/1460/1/012005.

${ }^{28}$ N S Meriyati, S Latifah, N Hidayah, A N Shawmi, M. A Amrullah and Fitriana, "Snake and Ladder Game Integrated with Asmaul-Husna: Development of Learning Media," Journal of Physics: Conference Series, 2019, https://doi.org/oi:10.1088/1742-6596/1155/1/012024. 
motivation, interest, morals, values, and religious identity to create a good social community.

\section{CONCLUSION}

The students need tools to assist learning, such as the use of media in the classroom. Therefore, this study aims to develop a game to solve student's problem of learning Islamic History Fathu Mecca. A game is defined as an activity that has defined rules. This research finding showed that the snake and ladder game significantly affects learning outcomes in studying Islamic history Fathu Mecca. This game helps students achieve higher scores and increases motivation and interest to memorize the Islamic history of Fathu Mecca. Therefore, the snake and ladder game must be implemented in the classroom and integrated with appropriate materials.

This study still has limitations of research samples. Research on the effectiveness of this learning medium still requires research with larger samples with more heterogeneous demographic conditions. Based on these findings, the next researcher could use a broader and varied sample to make the effectiveness of this medium more robust evidence.

\section{ACKNOWLEDGMENTS}

The author/s would like to thank for all the teachers, administration staffs and the students of SD Muhammadiyah Medan who helped and contributed in the research till finish.

\section{DECLARATION OF CONFLICTING INTERESTS}

The author/s declared no potential conflicts of interest with respect to the research, authorship, and/or publication of this article.

\section{FUNDING}

The author/s declared no funding for the research and publication of this article.

\section{ORCID iD}

Rora Rizky Wandini

(iD) https://orcid.org/0000-0002-2768-4612

Emeliya Sukma Dara Damanik

Sholihatul Hamidah Daulay

(iD) https://orcid.org/0000-0002-7660-8763

Wahyu Iskandar

https://orcid.org/0000-0001-8179-6271 


\section{REFERENCES}

Amin, Mohammad Latiful, Sri Sulistyorini, and Sugianto Sugianto. "The Increase of Students Science Cognitive Using Snake Ladder Media." Journal of Primary Education 8, no. 4 (February 4, 2019): 68-74. https://journal.unnes.ac.id/sju/index.php/jpe/article/view/28754.

Aprina, Heni. "The Influence Of Using Snake And Ladder Game Toward Students' Writing Ability In Recount Text At The First Semester Of The Tenth Grade Of SMAN 1 Ngambur Pesisir Barat In 2017/2018 Academic Year.” Undergraduate, UIN Raden Intan Lampung, 2018. http://repository.radenintan.ac.id/2988/.

Arshad, Izziah Suryani Mat Resad @, Ermy Azziaty Rozali, and Azmul Fahimi Kamaruzzaman. "The Importance of Learning Islamic History and Civilization of Malaysia in the Building of Human Capital and Identity of the Muslim Society in Malaysia." Procedia - Social and Behavioral Sciences, Universiti Kebangsaan Malaysia Teaching and Learning Congress 2011, Volume I, December 17 - 20 2011, Pulau Pinang MALAYSIA, 59 (October 17, 2012): 550-57. https://doi.org/10.1016/j.sbspro.2012.09.313.

Bierend, Doug. "The Timelessness of Snakes and Ladders." reform, 2015. https://medium.com/re-form/the-timelessness-of-snakes-and-ladders4ae7d205a4e7.

Delamarre, A., E. Shernoff, C. Buche, S. Frazier, J. Gabbard, and C. Lisetti. "The Interactive Virtual Training for Teachers (IVT-T) to Practice Classroom Behavior Management." International Journal of Human-Computer Studies 152 (August 1, 2021): 102646. https://doi.org/10.1016/j.ijhcs.2021.102646.

Fauziah, Ni'matul. "Faktor Penyebab Kejenuhan Belajar Sejarah Kebudayaan Islam (SKI) Pada Siswa Kelas XI Jurusan Keagamaan Di MAN Tempel Sleman." Skripsi, UIN Sunan Kalijaga Yogyakarta, 2013. https://doi.org/10/preview.jpg.

Hairul Aysa Abdul Halim Shitiq, R. Mahmud. "Using an Edutainment Approach of a Snake and Ladder Game for Teaching Jawi Script." In International Conference on Education and Management Technology. Malaysia, 2010. https://doi.org/DOI:10.1109/ICEMT.2010.5657667.

Ibam, E. O., T. A. Adekunle, and O. C. Agbonifo. "A Moral Education Learning System Based on the Snakes and Ladders Game." EAI Endorsed Transactions on ELearning 5, no. 17 (October 3, 2018). https://doi.org/10.4108/eai.25-92018.155641.

Jadhav, Pratibha. "A Study to Assess the Effectiveness of Snake and Ladder Game on Knowledge of Malnutrition among Schoolers in Selected School of Navi Mumbai." Int J Nurs Med Invest 5, no. 1 (2020): 6-10. https://doi.org/10.31690/ijnmi/57.

L Vitoria, R Ariska, Farha and Fauzi. "Teaching Mathematics Using Snakes and Ladders Game to Help Students Understand Angle Measurement." Journal of Physics: Conference Series, 2020. https://doi.org/0.1088/1742-6596/1460/1/012005.

Lindasari, Eva, Khairil Ansari, and Marice Marice. "Interactive Multimedia Development in Learning of Film Review Text for 8th Grade Students in Senior High School 
(SMP) 1 Tanjungmorawa." Budapest International Research and Critics in Linguistics and Education (BirLE) Journal 2, no. 4 (November 5, 2019): 355-62. https://doi.org/10.33258/birle.v2i4.522.

Mateer, G. Dirk. "Using Media to Enhance Teaching and Learning." Using Media to Enhance Teaching and Learning, 2020. https://serc.carleton.edu/sp/library/media/index.html.

Meipina. "The Application of Snakes and Ladders Game in Teaching Vocabulary." International Conference on Education and Language (ICEL) 2, no. 0 (May 22, 2014). http://artikel.ubl.ac.id/index.php/icel/article/view/311.

Meriyati, S Latifah, N Hidayah, A N Shawmi, M. A Amrullah, N S, and Fitriana. "Snake and Ladder Game Integrated with Asmaul-Husna: Development of Learning Media." Journal of Physics: Conference Series, 2019. https://doi.org/oi:10.1088/1742-6596/1155/1/012024.

Nachiappan, Suppiah, Nurain Abd. Rahman, Harikrishnan Andi, and Fatimah Mohd Zulkafaly. "Snake and Ladder Games in Cognition Development on Students with Learning Difficulties." Review of Arts and Humanities 3, no. 2 (June 2014): 217 29. http://rah-net.com/journals/rah/Vol_3_No_2_June_2014/15.pdf.

Nuryanti, Epi. "Development Of Snake And Ladder Game As A Learning Media In Special Journal Material To Improve Student Motivation Of Class X Accounting SMK Muhammadiyah 1 Tempel Academic Year 2016/2017.” Skripsi, Fakultas Ekonomi UNY, 2017. http://eprints.uny.ac.id/52263/.

Panjwani, Farid. "The 'Islamic' in Islamic Education: Assessing the Discourse." Current Issues in Comparative Education 7, no. 1 (December 15, 2004): 19-29. https://eric.ed.gov/?id=EJ853846.

Patmanthara, Syaad, Oki Yuliana, Felix Dwiyanto, and Aji Wibawa. "The Use of Ladder Snake Games to Improve Learning Outcomes in Computer Networking." International Journal of Emerging Technologies in Learning (IJET) 14, no. 21 (November 18, 2019): 243-49. https://www.learntechlib.org/p/217211/.

Perrotta, Carlo, Gill Featherstone, Helen Aston, and Emily Houghton. Game-Based Learning: Latest Evidence and Future Directions (NFER Research Programme: Innovation in Education). Slough, Berkshire: National Foundation fro Educational Research, 2013. https://www.nfer.ac.uk/nfer/publications/GAME01/GAME01.pdf.

Rusman. Model-Model Pembelajaran Mengembangkan Profesionalisme Guru. Jakarta: Rajawali Press, 2012.

Sugiyono. Metode Penelitian Pendidikan: Pendekatan Kuantitatif, Kualitatif Dan R\&D. Bandung: Alfabeta, 2016.

Suharsimi. Dasar Dasar Evaluasi Pendidikan. Jakarta: Bumi Aksara, 2016.

Swastrini, Km Cahya, S. Pd Putu Aditya Antara, and S. Psi Luh Ayu Tirtayani. "Penerapan Bermain Ular Tangga Untuk Meningkatkan Kemampuan Kerjasama Kelompok B1 Di TK Widya Sesana Sangsit.” Jurnal Pendidikan Anak Usia Dini Undiksha 4, no. 2 (July 22, 2016). https://doi.org/10.23887/paud.v4i2.7764. 
Topsfield, Andrew. "The Indian Game of Snakes and Ladders." Artibus Asiae 46, no. 3 (1985):

203-26.

https://doi.org/10.2307/3250203 https://www.jstor.org/stable/3250203.

Tsai, Meng-Ning, Yu-Fan Liao, Yu-Lin Chang, and Hsueh-Chih Chen. “A Brainstorming Flipped Classroom Approach for Improving Students' Learning Performance, Motivation, Teacher-Student Interaction and Creativity in a Civics Education Class." Thinking Skills and Creativity 38 (December 1, 2020): 100747. https://doi.org/10.1016/j.tsc.2020.100747.

Watson, Mariyln. Developmental Discipline and Moral Education. New York: Routledge, 2008.

Zikriyati, Zikriyati, and An Fauzia Rozani Syafei. "Teaching Vocabulary to Young Learners through Snake and Ladder Game." Journal of English Language Teaching 7, no. 1 (March 2, 2018): 208-15. https://doi.org/10.24036/jelt.v7i1.8480. 